\title{
ANTIBACTERIAL PROPERTIES OF HEMIAMINAL OF 2-METHYLIMIDAZOLE AND ITS INTERACTION WITH IONIC AND NON-IONIC SURFACTANTS
}

\author{
FLORIN AONOFRIESEI $^{1 \#}$, ANA CRISTINA SAMPAIO ${ }^{2}$, GABRIELA STANCIU $^{3 * *}{ }^{3 *}$, SIMONA $^{2}$ \\ LUPSOR $^{3 \#}$
}

${ }^{I}$ Faculty of Natural Sciences and Agricultural Sciences, Department of Biology-Ecology, “Ovidius” University of Constanța, 1 University Street, 900470, Constanța, Romania

${ }^{2}$ Centre for the Research and Technology of Agro-Environmental and Biological Sciences (CITAB), Universidade de Trás-osMontes e Alto Douro, Quinta de Prados, 5000-801, Vila Real, Portugal

${ }^{3}$ Department of Chemistry and Chemical Engineering, "Ovidius" University of Constanța, 124 Mamaia Boulevard, 900527, Constanța, Romania

*corresponding author: gstanciu66@yahoo.com

${ }^{*}$ Authors with equal contribution.

Manuscript received: December 2020

\begin{abstract}
The purpose of paper was to study the antibacterial activity of 2-methyl-1-hydroxymethylimidazole, the hemiaminal of 2methylimidazole (HIM) by using macrodilution broth method and time-kill assay. Average inhibitory activity of HIM was moderate and its ability to kill bacteria was variable, and displayed a concentration-dependent pattern. Most evident inhibitory activity of HIM was found for the two Staphylococcus strains which were killed in less than $2 \mathrm{~h}$ of exposure at 16 MIC while the response of Gram-negative strains was more variable as time-kill dynamics, depending on the bacterial species. Interaction of HIM with some surface active agents has been also evaluated and it was found that synergistic or antagonic effects were very limited between HIM, on the one hand, and SDS and polysorbate 80 (Tween 80), on the other.

\section{Rezumat}

Obiectivul lucrării a fost acela de a studia activitatea antibacteriană a 2-metil-1-hidroximetilimidazolului, hemiaminalul compusului 2-metilimidazol (HIM), prin metoda macrodiluției în bulion și testul mortalităţii în raport cu timpul de expunere. Activitatea inhibitorie medie a HIM a fost moderată, iar capacitatea sa de a distruge bacteriile a variat, manifestând un model de activitate dependent de timpul de expunere. Activitatea inhibitoare cea mai evidentă a fost observată în cazul a două tulpini de Staphylococcus aureus ce au fost distruse în mai puțin de $2 \mathrm{~h}$ de expunere la o concentrație echivalentă cu 16x CMI (concentrația minimă inhibitorie), în timp ce răspunsul tulpinilor Gram-negative a variat între limite largi sub aspectul mortalității în timp, în funcție de specia bacteriană respectivă. A fost, de asemenea, evaluată interacțiunea HIM cu o serie de surfactanți și s-a observat că efectele sinergice sau antagonice sunt foarte limitate între HIM, pe de o parte, și dodecil sulfat de sodiu (SDS) și polisorbat (Tween 80), pe de alta.
\end{abstract}

Keywords: imidazole, hemiaminal, antibacterial activity, surfactants

\section{Introduction}

Imidazole has been studied and still is intensely studied due to its wide range of bioactive properties useful to alleviate a variety of diseases. It has been shown that imidazole has anticancer, anti-inflammatory and antimicrobial potential $[28,34,35]$. Due to the increase in antibiotic-resistant pathogens, imidazole and its derivatives have proved to be a valuable tool to control the growth of a wide range of bacteria [12, 16, 22]. In the two previous papers we have dealt with antibacterial activity of some pyrazole, imidazole [17] and 2-methylimidazole derivatives [3]. It has been found that 1,1'-methanediylbis(2-methyl-1H-imidazole) AIM (Figure 1a), the aminal of 2-methylimidazole, has promising antibacterial activity $[3,17,18]$. As we

have stated before [17-19], the formation of aminal requires the removal of water from the system.<smiles>Cc1nccn1Cn1ccnc1C</smiles>

\section{Figure 1.}

b<smiles>Cc1nccn1CO</smiles>

Chemical structures of AIM (a) and HIM (b)

(a) = Aminal of 2-methylimidazole/1,1'methanediylbis(2-methyl-1H-imidazole), AIM

(b) = Hemiaminal of 2-methylimidazole/1hydroxymethyl-2-methylimidazole, HIM 
FARMACIA, 2021, Vol. 69, 2

The synthesis of tested hemiaminal of 2-methylimidazole was carried out by the microwave-assisted technique as it was previously reported [19]. The solid product was purified by column chromatography (silica gel) using tetrahydrofurane and petroleum ether $(1: 2)$ as eluent (order of elution: 2-methylimidazole and after 1,1'-methanediylbis(2-methyl-1H-imidazole) followed by sublimation. The molecular structure of 1,1'-methanediylbis(2-methyl-1H-imidazole) was confirmed by absorption spectra (FT-IR, $\left.{ }^{1} \mathrm{H}-\mathrm{NMR}\right)$ and mass spectra (MS) while the purity was established by HPLC-DAD. During experiments a series of conditions might favour in aqueous solutions (such as broth) a reversible reaction which generate hemiaminal from its respective aminal [19]. Taking into account this

possible transformation, the paper investigates the ability of HIM, hemiaminal of 2-methylimidazole (Figure 1b) [19] to inhibit the growth of 22 bacterial strains. The activity is analysed by determining MIC and minimal bactericidal concentration (MBC) as well as by time-kill assay.

\section{Materials and Methods}

Bacterial strains. Inhibitory activity of HIM was evaluated using 22 bacterial strains, most of them clinical strains collected from several laboratories in Constanța, Romania. Reference strains were purchased from BioMerieux (Table I).

Table I

Tested bacterial strains against HIM

\begin{tabular}{cll}
\hline Cr. No. & \multicolumn{1}{c}{ Strain } & \multicolumn{1}{c}{ Observations } \\
\hline 1 & Escherichia coli ATCC 25 922 & Reference strain \\
2 & E. coli U1 & Isolated from urinary tract infection (UTI) \\
3 & E. coli U2 & Isolated UTI \\
4 & E. coli U3 & Isolated UTI \\
5 & E. coli U4 & Isolated UTI \\
6 & E. coli U5 & Isolated UTI \\
7 & E. coli U6 & Isolated UTI \\
8 & Klebsiella sp. U1 & Isolated UTI \\
9 & Klebsiella sp. U2 & Isolated UTI \\
10 & Klebsiella sp. U3 & Isolated UTI \\
11 & Proteus sp. U1 & Isolated UTI \\
12 & Proteus sp. U2 & Isolated UTI \\
13 & Proteus sp. U3 & Isolated UTI \\
14 & Pseudomonas aeruginosa O1 & Isolated from otitis \\
15 & Pseudomonas aeruginosa O2 & Isolated from otitis \\
16 & Staphylococcus aureus ATCC 25 923 & Reference strain \\
17 & Staph. aureus 1 & Isolated from skin infection (SI) \\
18 & Staph. aureus 2 & Isolated from nasal exudate (NE) \\
19 & Staph. aureus 3 & Isolated SI \\
20 & Staph. aureus 4 & Isolated from NE \\
21 & Staph. aureus 5 & Isolated SI \\
22 & Staph. aureus 6 & Isolated from NE \\
\hline
\end{tabular}

Table II

Antibiotics used to test susceptibility of bacterial strains

\begin{tabular}{|c|c|c|c|}
\hline Cr. no. & Antibiotic & Concentration & Symbol \\
\hline 1 & amikacin & $30 \mathrm{mcg}$ & AK \\
\hline 2 & ampicillin & $10 \mathrm{mcg}$ & $\mathrm{AM}$ \\
\hline 3 & aztreonam & $30 \mathrm{mcg}$ & ATM \\
\hline 4 & cefazolin & $30 \mathrm{mcg}$ & $\mathrm{CZ}$ \\
\hline 5 & cefotaxime & $30 \mathrm{mcg}$ & CTX \\
\hline 6 & cefoxitin & $30 \mathrm{mcg}$ & FOX \\
\hline 7 & cefpodoxime & $10 \mathrm{mcg}$ & CPD \\
\hline 8 & ceftazidime & $30 \mathrm{mcg}$ & CAZ \\
\hline 9 & ceftriaxone & $30 \mathrm{mcg}$ & $\mathrm{CRO}$ \\
\hline 10 & ciprofloxacin & $5 \mathrm{mcg}$ & CIP \\
\hline 11 & clindamycin & $2 \mathrm{mcg}$ & DA \\
\hline 12 & erythromycin & $15 \mathrm{mcg}$ & $\mathrm{E}$ \\
\hline 13 & gentamicin & $10 \mathrm{mcg}$ & $\mathrm{CN}$ \\
\hline 14 & imipenem & $10 \mathrm{mcg}$ & IPM \\
\hline 15 & linezolid & $30 \mathrm{mcg}$ & LNZ \\
\hline 16 & methicillin & $5 \mathrm{mcg}$ & ME \\
\hline 17 & oxacillin & 1 & OX \\
\hline
\end{tabular}


FARMACIA, 2021, Vol. 69, 2

\begin{tabular}{clcc}
\hline Cr. no. & \multicolumn{1}{c}{ Antibiotic } & Concentration & Symbol \\
\hline 18 & penicillin g & $10 \mathrm{U}$ & $\mathrm{P}$ \\
19 & piperacillin & $30 \mathrm{mcg}$ & PRL \\
20 & piperacillin/tazobactam & $110 \mathrm{mcg}$ & TPZ \\
21 & tetracycline & $25 \mathrm{mcg}$ & TE \\
22 & tobramycin & $10 \mathrm{mcg}$ & TOB \\
23 & trimethoprim/sulfamethoxazole & $25 \mathrm{mcg}$ & SXT \\
24 & vancomycin & $30 \mathrm{mcg}$ & VA \\
\hline
\end{tabular}

Antibiotic susceptibility testing

Susceptibility of bacterial strains was performed against 24 antibiotics (Bioanalyse) (Table II) by using standard procedures [20, 21, 23]. Bacterial strains were grown overnight in Mueller-Hinton Broth (MHB-Oxoid) (composition $(\mathrm{g} / \mathrm{L})$ : casein hydrolysate, 17.5; beef infusion, 2.0; starch, $1.5 ; \mathrm{pH}=7.3$ ), then diluted to $5 \times 10^{5}-1 \times 10^{6} \mathrm{UFC} / \mathrm{mL}$ and inoculated onto MuellerHinton Agar (MHA-Oxoid) (composition (g/L): agaragar, 17.0; beef infusion, 2.0; starch, 1.5; casein hydrolysate, $17.5 ; \mathrm{pH}=7.3$ ). Incubation of MHA plates was done for $48 \mathrm{~h}$ at $37^{\circ} \mathrm{C}$ and susceptibility degree was assessed as described by Ortiz JH et al., [23]. In case of the Staphylococcus strains, several colonies grown overnight on Trypticase Soy Agar (TSA-BBL) (composition ( $\mathrm{g} / \mathrm{L}$ ): pancreatic digest of casein, 15.0; papaic digest of soybean, 5.0; sodium chloride, 5.0; agar, 15.0; $\mathrm{pH}=7.3$ ) were suspended in sterile saline solution to give cellular suspensions equal to $0.5 \mathrm{McFarland}$ standard. The other strains (e.g. E coli, Pseudomonas) were subcultured for $4-6 \mathrm{~h}$ to reach the log phase of growth. After their density was adjusted to $0.5 \mathrm{McF}$ arland, suspensions were inoculated on MHA. Plates were incubated for $18 \mathrm{~h}$ at $37^{\circ} \mathrm{C}$ and susceptibility was assessed as described by Ortiz JH et al., [23].

$M I C$ and $M B C$ evaluation

In order to assess the MIC (minimum inhibitory concentration) it has been used macrodilution broth method [24, 29]. HIM was diluted in Trypticase Soy Broth (TSB-BBL) (composition $(\mathrm{g} / \mathrm{L})$ : papaic digest of soybean, 3.0; pancreatic digest of casein, 17.0; sodium chloride, 2.5; dipotassium phosphate, 2.5; dextrose, $2.5 ; \mathrm{pH}=7.3$ ) at concentration ranging from 90 to $900 \mathrm{mcg} / \mathrm{mL}$. To reach mid-log phase overnight culture was suspended in TSB and further incubated for $4 \mathrm{~h}$ at $37^{\circ} \mathrm{C}$. An aliquote of culture $(10 \mu \mathrm{L})$ was inoculated in tubes containing TSB and HIM and incubated for $48 \mathrm{~h}$ at $37^{\circ} \mathrm{C}$. After visual examination, MIC was considered the highest concentration of HIM without growth. To determine MBC, tubes were vigorously shaken and $100 \mu \mathrm{L}$ of suspensions was sampled and plated out onto TSA. Incubation was done at $37^{\circ} \mathrm{C}$ for 48 - $72 \mathrm{~h}$. The lowest concentration of HIM able to kill over $99 \%$ of the initial bacterial populations was recorded as MBC [20].
Time-kill assay

Time-kill assay was carried out according to NCCLS procedure and has been described earlier [3]. Briefly, mid-log phase cultures were suspended in $25 \mathrm{~mL}$ sterile TSB to reach final concentration between 5 and $6 \times 10^{5}-1 \times 10^{6} \mathrm{UFC} / \mathrm{mL}$. HIM was added to give a concentration equivalent to $1,2,4,8$ and 16 MIC. Flasks have been agitated on rotatory shaker (GFL Shaking incubator 3033 , Germany) and kept at $37^{\circ} \mathrm{C}$ for a variable period of time (up to $8 \mathrm{~h}$ ). At different time interval $(1,2,3,4,6$ and $8 \mathrm{~h}) 100 \mu \mathrm{L}$ of culture were diluted in TSB and plated out onto TSA in triplicate. Inoculated plates were incubated for $24 \mathrm{~h}$ at $37^{\circ} \mathrm{C}$ and viable colonies were counted.

Interaction of HIM with surfactants

Potential interaction between HIM, sodium dodecyl sulphate (SDS) and polysorbate (Tween 80 ) has been investigated in a similar manner to kill-time method described as above. Each bacterial strain was inoculated in $100 \mathrm{~mL}$ Erlenmeyer flasks containing $50 \mathrm{~mL}$ TSB to give a final concentration equal to $5 \times 10^{5}-1 \times 10^{6}$ $\mathrm{UFC} / \mathrm{mL}$. Except control, one group of flasks received HIM, SDS and Tween 80 alone $(500 \mathrm{mcg} / \mathrm{mL})$ while the second group consisted of combination of HIM, SDS and Tween 80 as follows: HIM + SDS $(500+500$ $\mathrm{mcg} / \mathrm{mL}), \mathrm{HIM}+$ Tween $80(500+500 \mathrm{mcg} / \mathrm{mL})$ and $\mathrm{HIM}+\mathrm{SDS}+$ Tween $80(500+500+500 \mathrm{mcg} / \mathrm{mL})$. Every hour, $100 \mu \mathrm{L}$ of broth of all variants were sampled, diluted in TSB and plated out on TSA. After $24 \mathrm{~h}$ of incubation at $37^{\circ} \mathrm{C}$, viable colonies were counted and results were plotted versus time.

\section{Results and Discussion}

Diffusimetric test assay

Diffusimetric tests revealed a certain degree of resistance to antibiotics of $E$. coli isolates, against AM (E. coli U2, E coli U3, E coli U4), PRL (E coli 2 and $E$ coli 4 ) and SXT (E. coli 3). Clinical isolates of Klebsiella manifested a higher degree of resistance in comparison with former species $(E$. coli $)$. They were resistance against CZ, FOX (Klebsiella U2) and CPD (Klebsiella U3). At the same time, all isolates were resistant to CIP. Unlike these, Proteus was characterized by resistance only to AM (Table III). 
Table III

Sensitivity of tested bacterial strains against antibiotics ( $\mathrm{mm}$ zone of inhibition)

\begin{tabular}{lcccccccccccc}
\hline \multicolumn{1}{c}{ Strain/ } & E. coli & E coli & E. coli & E coli & E coli & E coli & E coli & Klebsiella & Klebsiella & Klebsiella & Proteus & Proteus \\
antibiotic & ATCC & 1 & 2 & 3 & 4 & 5 & 6 & sp. 1 & sp. 2 & sp. 3 & sp. U1 & sp. U2 \\
\hline AK & 18 & 16 & 25 & 21 & 17 & 18 & 19 & 20 & 19 & 15 & 15 & 20 \\
AM & 7 & 16 & 0 & 0 & 0 & 20 & 16 & 0 & 0 & 0 & 0 & 21 \\
ATM & 26 & 30 & 22 & 28 & 26 & 30 & 28 & 27 & 28 & 5 & 25 & 30 \\
CZ & 17 & 19 & 15 & 15 & 11 & 30 & 20 & 0 & 6 & 0 & 18 & 20 \\
CTX & 26 & 29 & 25 & 27 & 24 & 26 & 28 & 22 & 27 & 0 & 30 & 28 \\
FOX & 22 & 22 & 15 & 24 & 26 & 26 & 19 & 21 & 7 & 20 & 22 & 20 \\
CPD & 17 & 18 & 25 & 19 & 20 & 25 & 21 & 19 & 18 & 0 & 25 & 25 \\
CAZ & 21 & 22 & 17 & 22 & 22 & 24 & 23 & 20 & 20 & 0 & 25 & 30 \\
CRO & 24 & 25 & 23 & 25 & 24 & 32 & 28 & 25 & 24 & 0 & 25 & 30 \\
CIP & 30 & 21 & 30 & 7 & 27 & 32 & 30 & 0 & 0 & 0 & 30 & 30 \\
DA & 0 & 0 & 0 & 0 & 0 & 0 & 0 & 0 & 0 & 0 & 0 & 0 \\
E & 0 & 0 & 0 & 0 & 0 & 0 & 0 & 0 & 0 & 0 & 0 & 0 \\
CN & 16 & 16 & 14 & 17 & 15 & 20 & 16 & 0 & 8 & 0 & 15 & 18 \\
IPM & 21 & 23 & 17 & 21 & 25 & 19 & 23 & 21 & 23 & 20 & 19 & 18 \\
PRL & 18 & 20 & 6 & 6 & 0 & 20 & 21 & 0 & 0 & 0 & 20 & 21 \\
TPZ & 22 & 22 & 25 & 22 & 20 & 23 & 21 & 8 & 20 & 16 & 25 & 25 \\
TE & 17 & 17 & 15 & 12 & 15 & 0 & 17 & 16 & 16 & 0 & 0 & 0 \\
TOB & 16 & 14 & 12 & 13 & 13 & 14 & 16 & 0 & 0 & 0 & 15 & 15 \\
SXT & 24 & 23 & 18 & 0 & 25 & 25 & 25 & 9 & 20 & 0 & 0 & 20 \\
\hline mean & 18.00 & 18.57 & 16.00 & 14.68 & 16.31 & 20.21 & 19.52 & 10.94 & 12.42 & 4.00 & 16.26 & 19.52 \\
std. dev & 8.07 & 7.80 & 9.13 & 9.83 & 9.82 & 10.20 & 8.14 & 10.55 & 10.47 & 7.46 & 10.91 & 9.84 \\
Std. error & 1.85 & 1.79 & 2.09 & 2.25 & 2.25 & 2.34 & 1.86 & 2.42 & 2.40 & 1.71 & 2.50 & 2.25 \\
\hline
\end{tabular}

Table IV

Sensitivity of tested bacterial strains against antibiotics (mm zone of inhibition)

\begin{tabular}{|c|c|c|c|c|c|c|c|c|c|c|}
\hline $\begin{array}{c}\text { Strain/ } \\
\text { antibiotic }\end{array}$ & $\begin{array}{l}\text { Ps. aeruginosa } \\
\text { O1 }\end{array}$ & $\begin{array}{l}\text { Ps. aeruginosa } \\
\text { O2 }\end{array}$ & $\begin{array}{l}\text { Staph. aureus } \\
\text { ATCC }\end{array}$ & $\begin{array}{c}\text { Staph. } \\
\text { aureus } 1\end{array}$ & $\begin{array}{c}\text { Staph. } \\
\text { aureus } 2\end{array}$ & $\begin{array}{c}\text { Staph. } \\
\text { aureus } 3\end{array}$ & $\begin{array}{c}\text { Staph. } \\
\text { aureus } 4\end{array}$ & $\begin{array}{c}\text { Staph. } \\
\text { aureus } 5\end{array}$ & $\begin{array}{c}\text { Staph. } \\
\text { aureus } 6\end{array}$ & $\begin{array}{c}\text { Staph. } \\
\text { aureus } 7\end{array}$ \\
\hline $\mathrm{AK}$ & 20 & 18 & 15 & 17 & 20 & 15 & 16 & 18 & 16 & 9 \\
\hline $\mathrm{AM}$ & 0 & 0 & 30 & 14 & 10 & 0 & 6 & 6 & 10 & 0 \\
\hline ATM & 21 & 24 & 0 & 0 & 0 & 0 & 0 & 0 & 0 & 0 \\
\hline $\mathrm{CZ}$ & 0 & 0 & 30 & 25 & 26 & 0 & 25 & 25 & 26 & 0 \\
\hline CTX & 7 & 18 & 27 & 28 & 28 & 10 & 28 & 28 & 21 & 0 \\
\hline FOX & 0 & 0 & 27 & 28 & 28 & 11 & 28 & 26 & 28 & 0 \\
\hline CPD & 0 & 0 & 20 & 12 & 16 & 7 & 24 & 24 & 18 & 0 \\
\hline CAZ & 24 & 23 & 17 & & 12 & 0 & 6 & 16 & 15 & 0 \\
\hline CRO & 0 & 0 & 25 & 28 & 27 & 10 & 28 & 27 & 25 & 0 \\
\hline CIP & 34 & 32 & 22 & & 28 & 25 & 22 & 27 & 28 & 23 \\
\hline DA & 0 & 0 & 20 & 25 & 25 & 21 & 22 & 22 & 24 & 18 \\
\hline $\mathrm{E}$ & 0 & 0 & 17 & & 18 & 0 & 0 & 12 & 0 & 0 \\
\hline $\mathrm{CN}$ & 13 & 15 & 16 & 24 & 20 & 18 & 17 & 22 & 16 & 16 \\
\hline IPM & 19 & 19 & 30 & & 30 & 18 & 30 & 30 & 29 & 0 \\
\hline LNZ & $\mathrm{nt}$ & $\mathrm{nt}$ & 20 & 24 & 25 & 28 & 25 & 25 & 22 & 25 \\
\hline ME & $\mathrm{nt}$ & $\mathrm{nt}$ & 20 & 10 & 10 & 0 & 7 & 7 & 12 & 0 \\
\hline OX & $\mathrm{nt}$ & $\mathrm{nt}$ & 21 & & 15 & 0 & 19 & 19 & 17 & 0 \\
\hline $\mathrm{P}$ & $\mathrm{nt}$ & $\mathrm{nt}$ & 35 & 15 & 13 & 7 & 7 & 8 & 14 & 0 \\
\hline PRL & 18 & 21 & 30 & & 15 & 10 & 7 & 7 & 12 & 10 \\
\hline TPZ & 23 & 22 & 30 & 18 & 18 & 16 & 20 & 20 & 18 & 0 \\
\hline $\mathrm{TE}$ & 0 & 0 & 25 & & 17 & 10 & 5 & 24 & 12 & 9 \\
\hline TOB & 18 & 18 & nt & $\mathrm{nt}$ & nt & $\mathrm{nt}$ & $\mathrm{nt}$ & $\mathrm{nt}$ & $\mathrm{nt}$ & nt \\
\hline SXT & 0 & 0 & 15 & 27 & 25 & 23 & 26 & 26 & 27 & 22 \\
\hline VA & $\mathrm{nt}$ & $\mathrm{nt}$ & 15 & 18 & 20 & 15 & 14 & 17 & 16 & 15 \\
\hline Mean & 34.10 & 31.05 & 22.21 & 19.23 & 19.26 & 9.47 & 16.68 & 18.36 & 17.52 & 5.31 \\
\hline std. dev. & 48.24 & 40.54 & 7.88 & 8.66 & 8.16 & 9.23 & 10.22 & 9.08 & 8.52 & 8.74 \\
\hline Std. error & 11.06 & 9.30 & 1.80 & 2.40 & 1.87 & 2.11 & 2.34 & 2.08 & 1.95 & 2.00 \\
\hline
\end{tabular}

A particular situation was found in case of Pseudomonas aeruginosa when we recorded a highly resistance against ten antibiotics (Table IV). Overall, beyond species level the clinical isolates presented a diverse and variable response as antibiotic susceptibility pattern. Clinical isolates of Staphylococcus aureus were variable 
in their susceptibility to antibiotics, one of these (Staphylococcus aureus 7) exhibiting multiple resistance against AM, CZ, CTX, FOX, CPD, CAZ, CRO, E, IPM, OX and TPZ. As regard methicillin, all Staphylococcus isolates were resistant or exhibited an intermediate level of sensitivity (Table IV).

Time-kill assay

The ability of HIM to destroy E. coli was different, depending on the type of strain - reference or clinical isolates. HIM was able to kill in $4 \mathrm{~h}$ at $16 \mathrm{MIC}$ the whole cell population of E. coli ATCC 25922 (Figure 2).

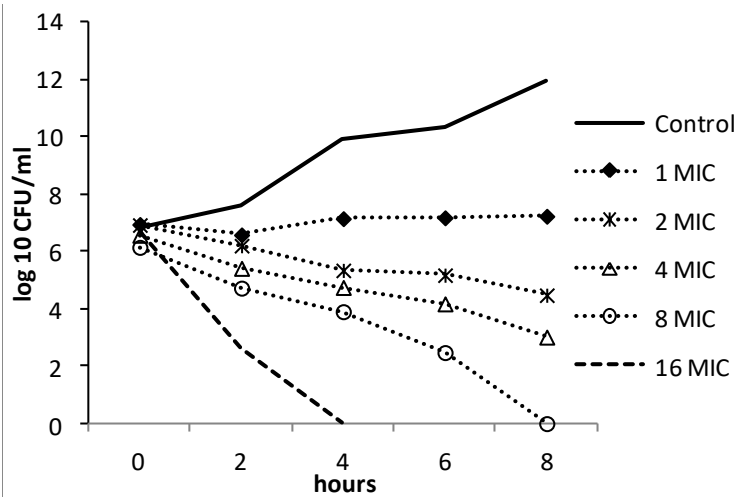

Figure 2.

Time-kill dynamics in E. coli ATCC 25922 exposed to HIM

Staphylococcus strain had more or less a similar trend, their populations being killed in $2 \mathrm{~h}$ at $16 \mathrm{MIC}$, but lower concentrations needed a longer time of exposure (Figure 3).

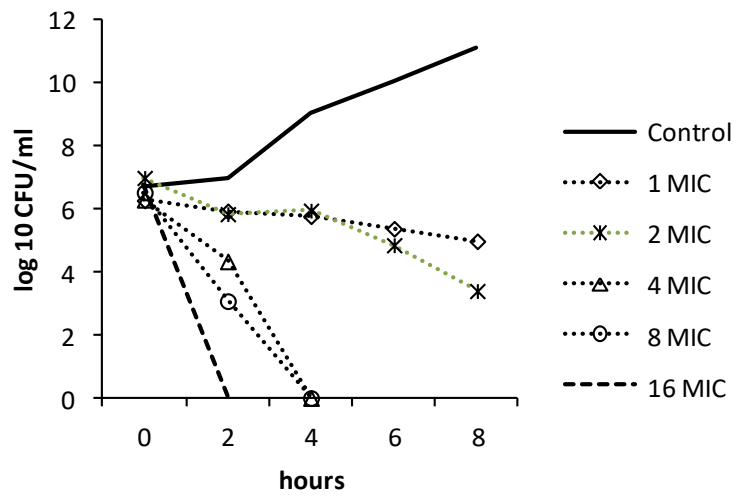

Figure 3.

Time-kill dynamics in Staphylococcus aureus ATCC 25923 exposed to HIM

On short-term experiments $(4 \mathrm{~h})$ at $500 \mu \mathrm{g} / \mathrm{mL}$, most sensitive to HIM were Pseudomonas and E. coli while Klebsiella and Proteus were more resistant and relatively more difficult to kill (Figure 4).

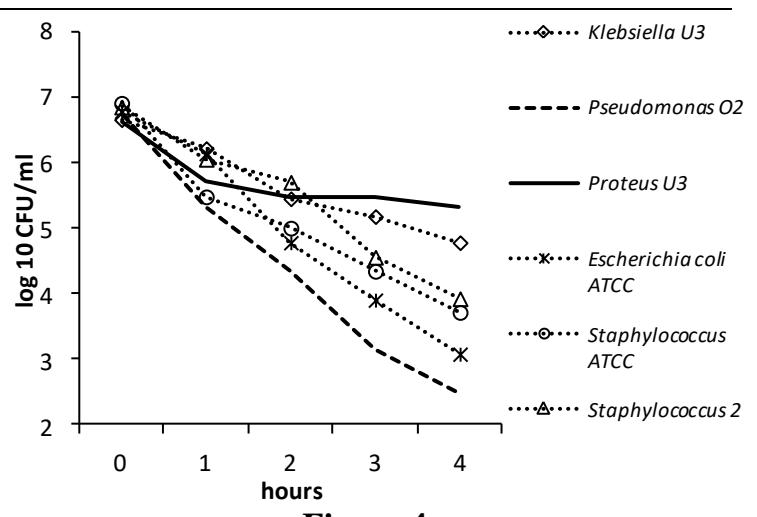

Figure 4.

Short-term effect $(4 \mathrm{~h})$ of defined concentration $(500 \mu \mathrm{g} / \mathrm{mL})$ on different Gram-positive and Gramnegative bacteria

Presented data support the idea of concentrationdependent pattern of HIM for most strains. The efficiency of such drugs increases with the increase of concentration $[2,6]$ and the pattern is characteristic to other such as aminoglycosides $[2,6]$.

Interaction of HIM with surfactants

There are reports supporting the idea that surface active agents might increase the susceptibility of some bacteria to antimicrobial agents [13]. Increased sensitivity to antimicrobials of certain bacterial strains after treatment with ionic and non-ionic compounds relies on the changes in cell membrane permeability and outer envelope hydrophobicity [25, 27]. Therefore, we sought it would be useful to investigate the potential interaction between HIM, SDS and Tween 80 by using time-kill method.

Tween 80 alone had apparently a stimulatory effect on almost strains as regard the cell multiplication and increased growth slightly above de control value (Figures 5, 6 and 7).

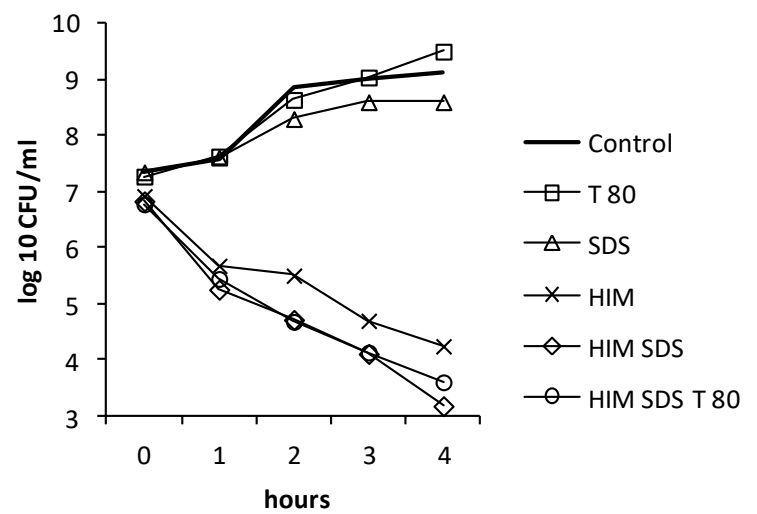

Figure 5.

Time-kill dynamics of E coli ATCC 25922 at different combinations of HIM, Tween 80 and SDS 
FARMACIA, 2021, Vol. 69, 2

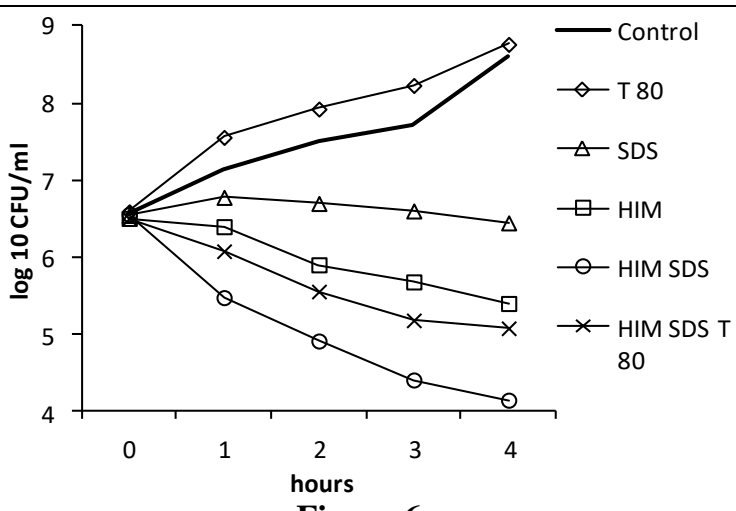

Figure 6.

Time-kill dynamics of Staphylococcus aureus ATCC 25922 at different combinations of HIM, Tween 80 and SDS

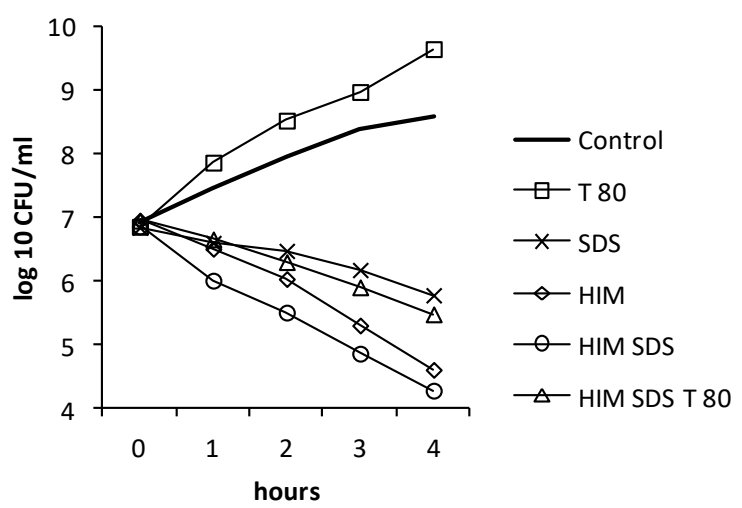

Figure 7.

Time-kill dynamics of $S$. aureus 6 at different combinations of HIM, Tween 80 and SDS

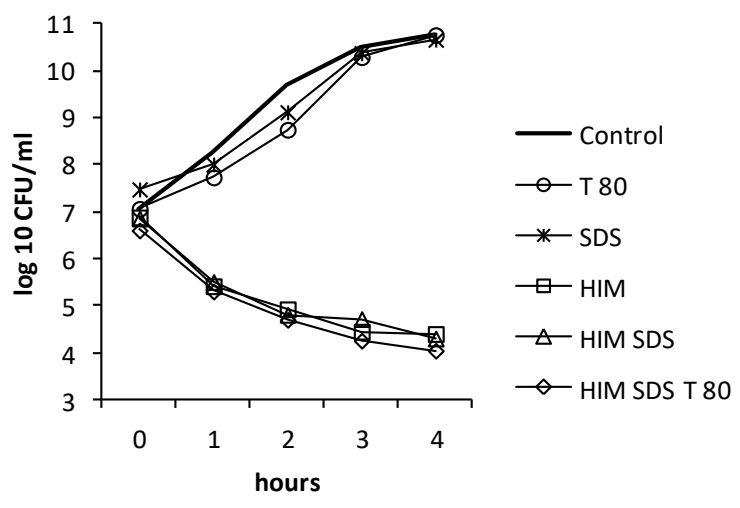

Figure 8.

Time-kill dynamics of Klebsiella U3 at different combinations of HIM, Tween 80 and SDS

SDS inhibited the growth in various degrees, depending on the bacterial species. Its effect was almost negligible on E. coli and Klebsiella (Figures 5 and 8), but the two strains of Staphylococcus presented a significant decrease of growth (Figures 6 and 7). On the other hand, association of HIM with SDS was a little more active in case of $E$ coli when it was recorded the enhancement of killing rate from $4.24 \log _{10}$ to 3.17 $\log _{10}$. Instead, in case of Klebsiella combination of
HIM + Tween $80+$ SDS had a minor effect on the growth (Figure 8).

Combination of HIM and SDS increased the efficiency of time-kill rate in Staphylococcus aureus ATCC 25923 from $5.4 \log _{10}$ to $4.1 \log _{10}$ in $4 \mathrm{~h}$ (Figure 6). Association of the two compounds (HIM and SDS) with Tween 80 decreased the rate of time-kill suggesting a protective role of Tween 80 most probably by optimizing the molecules exchange in bacterial cells. The same situation was observed in clinical strain of Staphylococcus aureus 6 when Tween 80 restricted to some extent the activity of HIM + SDS (Figure 7). In general, the increased killing rate of SDS + HIM combination is modest and lower than the sum of the two compounds, therefore insignificant to support the idea of synergistic effect between SDS and HIM. Tween 80 is a non-ionic surface active agent that may alter normal surface functioning of bacterial cell due to changes in membrane permeability and outer envelope hydrophobicity [1, 26, 27]. Changes of cell surface and increased membrane permeability might explain the enhanced effect of antimicrobials after treatment with surfactants [29]. In mycobacteria, Tween 80 altered colonial morphology and stimulate the in vitro growth $[31,32]$ effect which was observed also by us. In other situations, Tween 80 could inhibit biofilm formation on inorganic surfaces [30] and could increase the bactericidal activity of metronidazole and clarithromycin against Helicobacter pylori [9]. These reports showed that effect of Tween varied largely depending on bacterial species and their physiological properties (e.g. attached or planktonic cells). As regard SDS, it was observed a significant reduction of total viable counts of Listeria monocytogenes in the presence of benzalkonium chloride after initial exposure to SDS [33]. However, no significant changes in susceptibility were recorded in case of $E$. coli supporting our observations. Other reports showed that the cidal effect of detergent-like compounds was organism-dependent [10] and notably whether they Gram-positive or Gram-negative [33-37].

The rise in antibiotic resistance of bacteria has become a worldwide problem, especially during two last decades. Rapid increase of resistance frequency has been documented in beta-lactam class of antibiotics [68], quinolones [26], carbapenem [5], nalidixic acid, cotrimoxazole [11] colistin and polymyxines [4, 15]. Therefore, the need for new compounds active against especially Gram-negative bacteria is obvious as well as new combinations and strategies [17]. According to Wright and Brown [33] there are several strategies to overcome the dramatic increase in antibiotic resistance of bacteria. One useful strategy might be the use of compounds acting as antibiotic adjuvants [14]. In this sense, investigation of potential interaction between HIM and other antimicrobials might result in finding valuable combinations, especially for topical applications. Average killing activity of HIM is approximately 1.5 
higher than that found for AIM [3] and makes it a better candidate for further studies.

\section{Conclusions}

Time-kill dynamics showed in most cases significant inhibitory potential of HIM that manifested close similarities to concentration-dependent pattern of activity. A moderate potentiating effect was observed when HIM was used in combination with SDS. The presence of Tween 80 in this combination limited and neutralized in part the antibacterial activity of HIM and SDS. After the study of toxicity potential against mammalian cells, HIM might be useful to potentiate other selected topical antimicrobials, especially in disinfectant or preservative combinations.

\section{Conflict of interest}

The authors declare no conflict of interest.

\section{References}

1. Aase B, Sundheim G, Langsrud S, Rorvik LM, Occurrence of and a possible mechanism for resistance to a quaternary ammonium compound in Listeria monocytogenes. Int J Food Microbiol., 2000; 62(1-2): 57-63.

2. Andes D, In-vivo pharmacodynamics of amphotericin B against Candida albicans. Abstracts of the $39^{\text {th }}$ Interscience Conference on Antimicrobial Agents and Chemotherapy. Am. Soc. Microbiol. Washington DC, 1999.

3. Aonofriesei F, Lupsor S, Inhibitory potential of a novel imidazole derivative as evaluated by time-kill and dehydrogenase activity. Curr Microbiol., 2013; 66(2): 162-168.

4. Baadani AM, Thawadi SI, El-Khizzi NA, Omrani AS, Prevalence of colistin and tigecycline resistance in Acinetobacter baumannii clinical isolates from 2 hopitals in Riyadh Region over a 2-year period. Saudi Med J., 2013; 34(3): 248-253.

5. Centers for Disease Control and Prevention (CDC), Vital signs: carbapenem-resistant Enterobacteriaceae. Morb Mortal Wkly Rep (MMWR), 2013; 62(09): 165-170.

6. Craig WA, Pharmacodynamics of Antimicrobials: General Concepts and Applications. In: Antimicrobial Pharmacodynamics in Theory and Practice (Nightingale et al eds) Marcel Dekker New York, 2002; 1-23.

7. Davies J, Davies D, Origins and evolution of antibiotic resistance. Microbiol Mol Biol Rev., 2010; 74(3): 417-433.

8. Figura N, Marcolongo R, Cavallo G, Santucci A, Collodel G, Spreafico A, Moretti E, Polysorbate 80 and Helicobacter pylori: a microbiological and ultrastructural study. BMC Microbiol., 2012; 12: 217: 1-10.

9. Glover RE, Smith RR, Jones MV, Jackson SK, Rowlands CC, An EPR investigation of surfactant action on bacterial membranes. FEMS Microbiol Lett., 1999; 177: 57-62.

10. Hollyway K, Mathai E, Sorensen T, Communitybased surveillance use and resistance in resources- constrained settings: report on five projects. Geneva, World Health Organization, 2009.

11. Hugo WB, Russell AD, Pharmaceutical Microbiology, $7^{\text {th }}$ ed. Oxford: Blackwell Science Publications, 2004.

12. Jarashree A, Narayana B, Gauthama BU, Ghate VM, Lewis SA, Prakash B, Kunhanna SB, Kumar MS, ZnO Nanocatalyst Mediated Convergent Synthesis of Highly Substituted Imidazole and Imidazole-derived Bi-heterocyclic Scaffolds as Potential Antibacterial Agents. J Heterocyclic Chem., 2019; 56(9): 2398-2410.

13. Kalan L, Wright GD, Antibiotic adjuvants: multicomponent anti-infective strategies. Exp Rev Mol Med., 2011; 13: e5: 1-17.

14. Ko KS, Suh JY, Kwon KT, Jung SI, Park KH, Kang CI, Chung DR, Peck KR, Song JH, High rates of resistance to colistin and polymyxin $\mathrm{B}$ in subgroups of Acinetobacter baumannii isolates from Korea. $J$ Antimicrob Chemother., 2007; 60(5): 1163-1167.

15. Laxminarayan R, Duse A, Wattal C, Zaidi AK, Wertheim HF, Sumpradit N, Vlieghe E, Hara GL, Gould IM, Goossens H, Greko C, So AD, Bigdeli M, Tomson G, Woodhouse W, Ombaka E, Peralta AQ, Qamar FN, Mir F, Kariuki S, Bhutta ZA, Coates A, Bergstrom R, Wright GD, Brown ED, Antibiotic resistance-the need for global solutions. Lancet Infect Dis., 2013; 13(12): 1057-1098. Erratum in: Lancet Infect Dis., 2014; 14(1): 11. Erratum in: Lancet Infect Dis., 2014; 14(3): 182.

16. Li ZZ, Tangadanchu VKR, Battini N, Bheemanaboina RRY, Zang ZL, Zhang SL, Zhou CH, Indolenitroimidazole conjugates as efficient manipulators to decrease the genes expression of methicillin-resistant Staphylococcus aureus. Eur J Med Chem., 2019; 179: 723-735.

17. Lupsor S, Aonofriesei F, Iovu M, Antibacterial activity of aminals and hemiaminals of pyrazole and imidazole. Med Chem Res., 2012; 21(10): 3035-3042.

18. Lupsor S, Uivarosi V, Iovu M, Rapid Synthesis of Azole Aminals under Microwave Heating Conditions. Rev Chim., 2010; 61(3): 333-335.

19. Lupsor S, Tarcomnicu I, Aonofriesei F, Iovu M, Microwave-Assisted Synthesis of 1-Hydroxymethylazoles. Rev Chim., 2011; 62(5): 493-498.

20. National Committee for Clinical Laboratory Standards (NCCLS), Methods for determining bactericidal activity of antimicrobial agents. Approved guideline M26-A. NCCLS, Wayne, Pa., 1999.

21. National Committee for Clinical Laboratory Standards (NCCLS). Performance standards for antimicrobial disk susceptibility tests. Approved standard, $8^{\text {th }}$ ed. Document M2-A8. NCCLS, Wayne, Pa., 2003.

22. Obaleye JA, Ajibola AA, van Bernardus B, Hosten EC, Synthesis, X-ray crystallography, spectroscopic and in vitro antimicrobial studies of a new $\mathrm{Cu}$ (II) complex of trichloroacetic acid and imidazole. $J$ Molec Struct., 2020, 1203: 127435: 1-6.

23. Ortiz JH, Disk diffusion testing. In: Manual of Antimicrobial Susceptibility Testing, M B Coyle (ed) American Society for Microbiology, 2005; 39-53.

24. Pearson DR, Steigbigel RT, Davis HT, Method for reliable determination of minimal lethal antibiotic concentration. Antimicrob Agents Chemother., 1980; 8(5): 699-708. 
25. Poole K, Mechanisms of bacterial biocide and antibiotic resistance. J Appl Microbiol Symp Suppl., 2002; 92: 55S-64S.

26. Ruiz J, Pons MJ, Gomes C, Transferable mechanisms of quinolone resistance. Int J Antimicrob Agents, 2012; 40: 196-203.

27. Russell AD, Antibiotic and biocide resistance in bacteria: comments and conclusions. J Appl Microbiol Symp Supp., 2002; 92: 171S-173S.

28. dos Santos Nascimento MVP, Mattar Munhoz AC, de Campos Facchin BM, Fratoni E, Rossa TA, Mandolesi SáM, Campa CC, Ciraolo E, Hirsch E, Dalmarco EM, New pre-clinical evidence of anti-inflammatory effect and safety of a substituted fluorophenyl imidazole. Biomed Pharmacother., 2019; 111: 1399-1407.

29. Taylor PC, Schoenknecht FD, Sherris JC, Linner EC, Determination of minimum bactericidal concentration of oxacillin for Staphylococcus aureus: influence and significance of technical factors. Antimicrob Agents Chemother., 1983; 23(1): 142-150.

30. Toutain-Kidd CM, Kadivar SC, Bramante CT, Bobin SA, Zegans ME, Polysorbate 80 inhibition of Pseudomonas aeruginosa biofilm formation and its cleavage by the secreted lipase LipA. Antimicrob Agents Chemother., 2009; 53(1): 136-145.

31. Van Boxtel RM, Lambrecht RS, Collins MT, Effect of polyoxyethylene sorbate compounds (Tweens) on colonial morphology, growth, and ultrastructure of Mycobacterium paratuberculosis. APMIS, 1990; 98(10): 901-908.
32. Walton JT, Hill DJ, Protheroe RG, Nevill A, Gibson $\mathrm{H}$, Investigation into the effect of detergents on disinfectant susceptibility of attached Escherichia coli and Listeria monocytogenes. J App Microbiol., 2008; 105: 309-315.

33. Wright GD, Brown ED, Part 8: Beyond antibiotics alternative strategies for prevention and treatment, In: The Lancet Infectious Diseases Commission, Antibiotic resistance - the need for global solutions, 2013; 27-31.

34. Al Jourdi H, Popescu C, Udeanu DI, Arsene A, Sevastre A, Velescu BS, Lupuliasa D, Comparative study regarding the physico-chemical properties and microbiological activities of Olea Europaea L. oil and Cannabis Sativa L. seed oil obtained by cold pressing. Farmacia, 2019; 67(5): 759-763.

35. Zhang L, Peng XM, Damu GL, Geng RX, Zhou CH, Comprehensive review in current developments of imidazole-based medicinal chemistry. Med Res Rev., 2014; 34(2): 340-437.

36. Stecoza CE, Drăghici C, Căproiu MT, Grădișteanu Pîrcălăbioru G, Măruțescu L, Synthesis and evaluation of the antimicrobial and antibiofilm activity of novel dibenzothiepines. Farmacia, 2020; 68(6): 1091-1098.

37. Zhang L, Ge $\mathrm{Y}$, Wang QM, Zhou CH, Identification of novel imidazole flavonoids as potent and selective inhibitors of protein tyrosine phosphatase. Bioorg Chem., 2019; 88: 102900: 1-14. 